Salomo Christian, Wahyu Irawati. (2019). Uji Resistensi Isolat Khamir yang Diisolasi dari Limbah Industri di Rungkut, Surabaya, Indonesia. Jurnal Bioeksperimen. Vol. 5 (1) Pp. 1-10. Doi: 10.23917/bioeksperimen.v5i1.2795

\title{
UJI RESISTENSI ISOLAT KHAMIR YANG DIISOLASI DARI LIMBAH INDUSTRI DI RUNGKUT, SURABAYA, INDONESIA
}

\author{
Salomo Christian ${ }^{1)}$; Wahyu Irawati ${ }^{2)^{*}}$ \\ ${ }^{1}$ Fakultas Ilmu Pendidikan, Program Studi Pendidikan Biologi, \\ ${ }^{2}$ Fakultas sains dan Matematika, Program Studi Biologi, \\ Universitas Pelita Harapan \\ Jalan M.H. Thamrin Boulevard 1100, Lippo Karawaci, Tangerang 15811, Indonesia \\ *Email : w.irawati3@gmail.com
}

\begin{abstract}
Abstrak
Pencemaran tembaga di daerah Rungkut-Surabaya telah melebihi ambang batas sehingga dapat mengancam kehidupan organisme di laut. Tembaga tidak dapat didegradasi dan beracun pada konsentrasi tinggi sehingga diperlukan pengolahan limbah yang dapat menurunkan konsentrasi tembaga di lingkungan. Khamir resisten tembaga dapat diisolasi dari daerah tercemar dan dapat dijadikan sebagai agen bioremediasi untuk mengatasi pencemaran tembaga. Penelitian ini bertujuan untuk melakukan isolasi dan uji resistensi khamir resisten tembaga dari limbah industri. Sampel diambil dari lumpur aktif pusat pengolahan limbah PT. SIER Surabaya. Isolasi dilakukan dengan pengenceran sampel limbah kemudian diinokulasikan dengan metode sebar ke dalam medium Yeast Extract Peptone Dextrose Agar yang diperkaya dengan $\mathrm{CuSO}_{4}$. Uji resistensi dilakukan dengan menginokulasikan isolat murni dengan metode gores ke dalam medium Agar yang mengandung berbagai konsentrasi $\mathrm{CuSO}_{4}$ untuk menentukan nilai Minimum Inhibitory Concentration (MIC). Hasil isolasi diperoleh delapan isolat khamir dengan kode ES6.1, ES8.1, ES9.2, ES9.3, ES9.4, ES9.5, ES10.2, dan ES10.4. Nilai MIC isolat khamir tersebut berkisar antara 16-20 $\mathrm{Mm} \mathrm{CuSO}_{4}$. Isolat yang paling resisten adalah isolat dengan kode ES9.3 dengan nilai $\mathrm{MIC}=20 \mathrm{mM} \mathrm{CuSO}_{4}$, sehingga isolate ini dipilih sebagai isolate yang paling resisten terhadap polutan di Wilayah Rungkut, Surabaya, Indonesia.
\end{abstract}

Kata kunci: Isolasi, karakterisasi, khamir, resistensi, tembaga, isolate ES9.3

\begin{abstract}
Copper pollution in Rungkut-Surabaya area has exceeded the threshold so that it can be threaten the life of organisms in the sea. Copper cannot be degraded and its very toxic at high concentrations. So that, we need to treat the water waste to reduce copper concentrations. Copper yeast can be isolated from polluted areas and can be used as a bioremediation agent to overcome copper pollution. This study aims to conduct copper isolation and yeast resistance testing from industrial waste. Samples taken from the activated sludge of PT. SIER Surabaya. Isolation was carried out by dilution of the waste sample and then inoculated with the scatter method into Yeast Extract medium Peptone Dextrose Agar enriched with $\mathrm{CuSO}_{4}$. The resistance test was carried out by inoculating the pure isolate with the scratch method into Agar medium containing various concentrations of $\mathrm{CuSO}_{4}$ to determine the value of Minimum Inhibitory Concentration (MIC). The isolation results obtained eight yeast isolates with the code ES6.1, ES8.1, ES9.2, ES9.3, ES9.4, ES9.5, ES10.2, and ES10.4. The MIC value of yeast isolates ranged from 16-20 Mm CuSO4. The most resistant isolates were isolates with code ES9.3 with MIC $=20 \mathrm{mM} \mathrm{CuSO}_{4}$ so that this isolate was chosen as the most resistant isolate to pollutants in the Rungkut Region, Surabaya, Indonesia.
\end{abstract}

Keywords: Isolation, characterization, yeast, resistance, copper, isolate ES9.3

\section{Pendahuluan}

Logam berat merupakan polutan yang tidak dapat didegradasi dan cenderung terakumulasi di dalam tubuh organisme. Logam berat dapat menjadi polutan karena merupakan senyawa sisa yang dihasilkan dari industri (Kobya, Demirbas, Senturk, \& Ince, 2005). Tembaga adalah logam berat yang banyak digunakan di dalam industri terutama industri elektronik dan bersifat toksik bagi organisme (Davis, Volesky, \& Vieira, 2000). Tembaga merupakan salah satu logam berat esensial dan diperlukan oleh manusia dalam konsentrasi yang sangat kecil, yaitu tidak lebih dari $0,05 \mathrm{mg} / \mathrm{kg}$ berat badan yaitu untuk membentuk hemoglobin dan kolagen, tetapi akan menjadi racun jika konsentrasi 
tembaga tersebut melebihi tingkat kebutuhan harian. Akumulasi tembaga di dalam tubuh manusia dapat mengakibatkan berbagai macam penyakit seperti gagal ginjal, kanker, kerusakan liver, kerusakan otak, gangguan saraf, bahkan kematian (Hocheng, Chakankar, \& Jadhav, 2018).

Pencemaran tembaga di pantai timur Surabaya merupakan salah satu kasus pencemaran logam berat yang terjadi di Indonesia yang belum dapat ditanggulangi. Pencemaran ini dapat terjadi karena adanya pembuangan limbah cair ke sungai oleh industriyang berada di sekitar pantai timur Surabaya. Akibat yang ditimbulkan dari pencemaran tembaga adalah akumulasi tembaga oleh hewan yang hidup di sungai dan laut di sekitarnya seperti ikan, kerang, dan udang. Hewan-hewan yang mengakumulasi logam berat bila terkonsumsi oleh manusia dalam jangka panjang dapat menimbulkan kerusakan pada beberapa organ tubuh (Irawati, Parhusip, Christian, \& Yuwono, 2017).

Data pencemaran logam berat menunjukkan bahwa kadar $\mathrm{Cu}$ pada ikan dan kerang dari pantai sekitar muara yang berasal dari Rungkut, yaitu pantai di kelurahan Sukolilo mengandung 2.290,20 ppb dan 5.920,20 ppb. Pencemaran di Rungkut telah melebihi ambang batas yang ditentukan oleh World Health Organization (WHO) yaitu 1.200 ppb sehingga dapat membahayakan kesehatan penduduk yang tinggal di desa tersebut.

Masalah kontaminasi tembaga di lingkungan telah dilakukan di beberapa daerah industri tetapi untuk mendegradasi dan menghilangkan logam berat tidak semudah mendegradasi limbah organik karenalimbahlogamberatbersifatnonbiodegradable. Degradasi dan reduksi logam berat dari lingkungan untuk skala kecil dapat dilakukan dengan cara fisik dan kimia melalui pertukaran ion (ion exchange), presipitasi, koagulasi, inverse osmosis, dan adsorpsi. Metode-metode tersebut cukup efisien dalam mengurangi kontaminasi logam berat tetapi akan sangat merugikan bila digunakan untuk mengolah limbah industri yang sangat banyak sehingga akan menimbulkan masalah baru, yaitu biaya pengolahan limbah yang relatif mahal, membutuhkan energi dan bahan kimia cukup banyak (Jianlong, 2002).

Pendekatan secara bioteknologi dengan menggunakan khamir merupakan alternatif yang dapat dilakukan untuk masa yang akan datang dan merupakan langkah yang cukup berpotensi dalam meremediasi limbah cair yang mengandung logam berat. Mikroorganisme dapat mengurangi konsentrasi logam berat di lingkungannya melalui proses adsorpsi, produksi senyawa ekstraseluler, maupunsintesisenzimatis. Berbagai mikroorganisme memiliki toleransi terhadap logam pada konsentrasi yang lebih tinggi setelah ditumbuhkan pada medium yang mengandung logam berat (Irawati, Riak, Sopiah, \& Sulistia, 2017).

Hasil penelitian menunjukkan bahwa beberapa jenis khamir seperti Saccharomyces pombe strain 972, Saccharomyces cerevisiae, dan Candida tropicalis dapat mengabrsopsi tembaga di dalam medium masing-masing sebesar $70 \%$, 86\%, dan 82\% (Stephen, 1992; Rahman, 2007). Mekanisme detoksifikasi tembaga pada khamir pada umumnya adalah dengan cara pengikatan ion tembaga pada membran, penyerapan ke dalam sel, dan dilanjutkan dengan pengikatan ion tembaga oleh protein metallothionein (MT) (Ashish, Neeti, \& Himanshu, 2013). Eksplorasi khamir resisten tembaga yang dapat mengakumulasi tembaga perlu dilakukan untuk mendukung program bioremediasi limbah tembaga di Indonesia demi terciptanya lingkungan yang terbebas dari kontaminasi logam berat.

Tingkat kontaminasi limbah tembaga di banyak daerah industri di Indonesia telah melebihi ambang batas dan perlu ditanggulangi untuk menghentikan pencemaran limbah tembaga ke lingkungan. Khamir resisten tembaga merupakan mikroorganisme yang sangat berpotensi dalam mengakumulasi tembaga dari limbah dalam proses bioremediasi tetapi penelitian mengenai isolasi dan karakterisasi khamir resisten tembaga belum banyak dilakukan di Indonesia (Qayyum, Khan, Maqbool, Zhao, \& Peng, 2016) (Jianlong, 2002). Eksplorasi khamir resisten tembaga dari daerah industri Rungkut-Surabaya sangat penting untuk dilakukan sebagai langkah awal dalam rangka mendapatkan solusi dalam meremediasi lingkungan yang telah tercermar logam berat. Penelitian ini bertujuan untuk mengisolasi dan menguji resistensi khamir resisten tembaga dari limbah industri Rungkut Surabaya. 


\section{Material dan Metode}

\section{Medium Pertumbuhan}

Medium yang digunakan di dalam penelitian ini adalah medium pertumbuhan YEPD (Yeast Extract Peptone Dextrose) agar komposisi $1 \%$ yeast extract, $2 \%$ peptone, $2 \%$ dextrose, dan tambahan $1,5 \%$ bacto agar yang diperkaya dengan $\mathrm{CuSO}_{4}$. Pembuatan medium dilakukan dengan cara menimbang 1 gram yeast extract, 2 gram peptone, dan 2 gram dextrose kemudian dilarutkan di dalam $100 \mathrm{ml}$ akuades di dalam labu erlenmeyer berkapasitas $250 \mathrm{ml}$. Medium yang sudah tercampur dengan akuades kemudian disterilisasi menggunakan autoklaf dengan suhu pemanasan $121^{\circ} \mathrm{C}$ selama kurang lebih 2 jam. Penambahan $\mathrm{CuSO}_{4}$ pada konsentrasi tertentu diberikan secara aseptis pada medium yang telah disterilkan.

\section{Isolasi Khamir Resisten Tembaga}

Isolasi khamir dilakukan dengan cara mengambil sampel limbah industri dari RungkutSurabaya berupa lumpur aktif (active sludge) yang mengandung logam berat tembaga ke laboratorium menggunakan toples kaca yang ditutup dengan aluminium foil kemudian dilakukan pengenceran hingga tingkat pengenceran $10^{-5}$. Hasil pengenceran $10^{-3}, 10^{-4}$, dan $10^{-5}$ kemudian disebar (spread) pada medium pertumbuhan $50 \%$ YEPD agar pada cawan petri dan diinkubasi pada $37^{\circ} \mathrm{C}$ selama 24 jam. Masing-masing koloni berbeda yang tumbuh di permukaan agar diseleksi dan dimurnikan ke dalam medium YEPD baru yang sudah mengandung $\mathrm{CuSO}_{4}$ sebesar $5 \mathrm{mM}$ dengan metode gores (streak) dengan empat kuadaran sampai mendapatkan koloni tunggal. Khamir yang telah dimurnikan selanjutnya diinokulasikan di dalam YEPD agar miring dan disimpan di dalam lemari es untuk disimpan maksimal 2 minggu dan dibuat kultur gliserol untuk diawetkan (Irawati, et al., 2012).

\section{Karakterisasi Isolat Khamir Resisten Tembaga}

Karakterisasi morfologi koloni khamir resisten tembaga dilakukan dengan pengamatan ciri-ciri morfologi koloni diantaranya: ukuran, bentuk, tepian, karakteristik optik, warna, permukaan, dan elevasi.
Karakterisasi morfologi sel khamir resisten tembaga dilakukan dengan pewarnaan sederhana menggunakan methylene blue kemudian diamati menggunakan mikroskop dengan perbesaran objektif 40x dan 100x. Pewarnaan sederhana juga dilakukan untuk membedakan sel yang hidup (viable) dan yang mati. Karakteristik khamir dapat dilihat apabila terbentuk budding pada sel khamir (Fankhauser, 2005).

\section{Uji Resistensi Isolat Khamir terhadap Tembaga \\ Uji resistensi dilakukan dengan menentukan} nilai minimum inhibitory Concentration (MIC) isolat terhadap tembaga. Isolat khamir diinokulasikan dengan metode cawan gores pada medium pertumbuhan YEPD agar yang mengandung $\mathrm{CuSO}_{4}$ dengan konsentrasi bertahap mulai dari $5 \mathrm{mM}$ dan diinkubasi pada suhu $37^{\circ} \mathrm{C}$ selama 7 hari. Isolat yang tumbuh diinokulasikan kembali pada konsentrasi $\mathrm{CuSO}_{4} 6 \mathrm{mM}$ sampai $20 \mathrm{mM}$ atau hingga diperoleh batas minimum konsentrasi yang mulai menghambat pertumbuhan bakteri (MIC) (Brady, 1992; Kunito et al., 1997a).

\section{Hasil dan Pembahasan}

\section{Isolasi dan Karakterisasi Khamir Resisten Tembaga}

Hasil Isolasi khamir resisten tembaga dari pusat pengolahan limbah di Rungkut-Surabaya diperoleh delapan isolat khamir dengan kode ES6.1, ES8.1, ES9.2, ES9.3, ES9.4, ES9.5, ES10.2, dan ES10.4 (Gambar 1).

Setiap isolat yang telah diwarnai dengan methylen blue diamati di mikroskop pada perbesaran 100x memiliki bentuk yang tidak jauh berbeda antara satu dengan yang lainnya, yaitu berbentuk oval (Gambar 1). Isolat tersebut sebelumnya telah dilakukan pewarnaan gram tetapi tidak dapat ditentukan gramnya karena berdasarkan hasil yang didapat, sel yang terwarnai berwarna biru gelap dan beberapa diantaranya cenderung berwarna kehitaman, hal ini terjadi karena isolat tersebut bukan merupakan bakteri tetapi khamir sehingga tidak sesuai untuk dilakukan pewarnaan menggunakan pewarnaan gram. Ketidaksesuaian ini terkait dengan ketidakberadaan peptidoglikan 
pada dinding sel khamir, karena dinding sel khamir tersusun atas senyawa kitin (Wan, et al., 2008).

Pada beberapa bidang pandang pada pengamatan dengan mikroskop, beberapa sel sedang membentuk budding. Hasil tersebut menunjukkan bahwa isolat yang didapat bukan merupakan bakteri melainkan yeast (khamir). Hasil ini sesuai dengan pendapat (Herskowitz, 1988) yang mengemukakan bahwa khamir dapat membentuk budding dalam rangka bereproduksi (Gambar 1).

Uji Resistensi Isolat Khamir Resisten Tembaga Hasil pengujian resistensi masing-masing isolat lainnya Gambar 2 - 9).

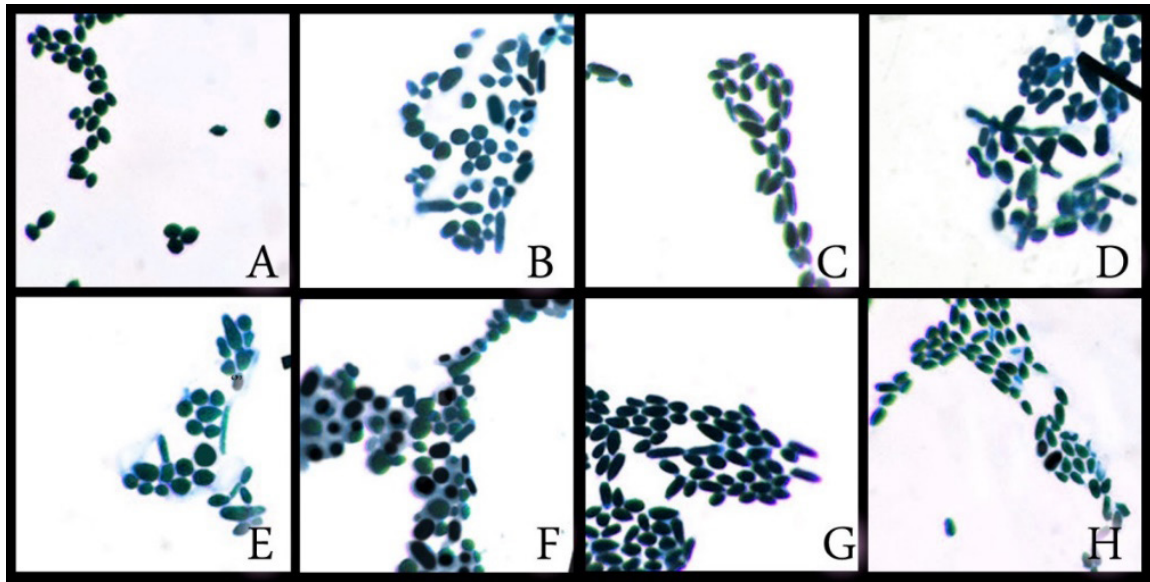

Gambar 1. Morfologi sel isolat khamir resisten tembaga dengan pewarnaan methylen blue pada mikroskop dengan perbesaran objektif 100x

Keterangan: A. ES6.1; B. ES8.1; C. ES9.2; D. ES9.3; E. ES9.4; F.ES9.5; G.ES10.2; dan H. ES10.4

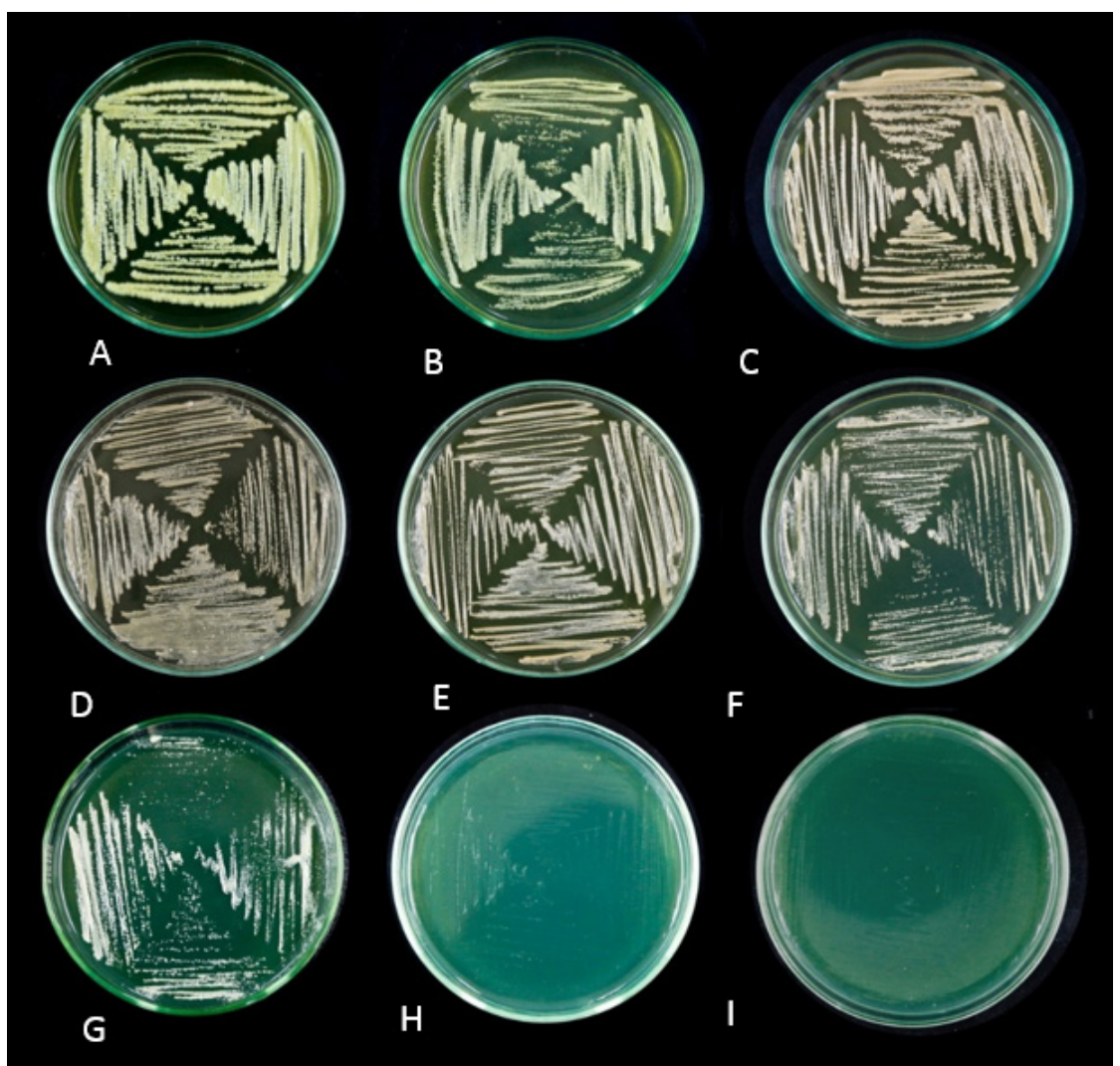

Gambar 2. Hasil uji resistensi isolat khamir ES6.1 pada medium yang mengandung berbagai konsentrasi $\mathrm{CuSO}_{4}$. Berturut-turut dari A-I adalah: 5 mM, $7 \mathrm{mM}, 9 \mathrm{mM}, 11 \mathrm{mM}, 13 \mathrm{mM}, 15 \mathrm{mM}, 16 \mathrm{mM}, 17 \mathrm{mM}, 18 \mathrm{mM}$.

Isolat ES6.1 tidak mengalami pertumbuhan pada medium yang mengandung $17 \mathrm{mM} \mathrm{CuSO}_{4}$ 
(Gambar 2). Hal ini menunjukkan bahwa isolat ES6.1 memiliki nilai MIC sebesar $17 \mathrm{mM} \mathrm{CuSO}_{4}$. Isolat ES8.1 tidak mengalami pertumbuhan pada medium yang mengandung $18 \mathrm{mM} \mathrm{CuSO}_{4}$
(Gambar 3). Hal ini menunjukkan bahwa isolat ES8.1 memiliki nilai MIC sebesar $18 \mathrm{mM} \mathrm{CuSO}_{4}$.

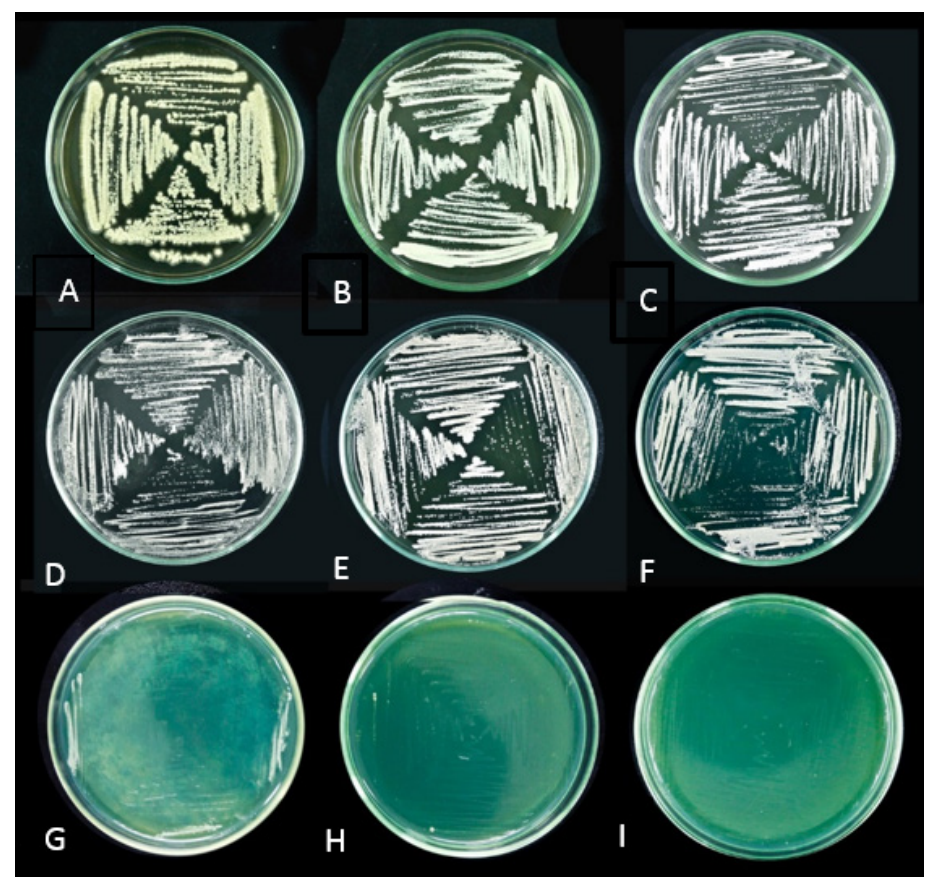

Gambar 3. Hasil uji resistensi isolat khamir ES8.1

pada medium yang mengandung berbagai konsentrasi $\mathrm{CuSO}_{4}$. Berturut-turut dari A-I adalah: 5 mM, 7 mM, 9 mM,11 mM, 13 mM, 15 mM, 17 mM,18 mM, 19 mM
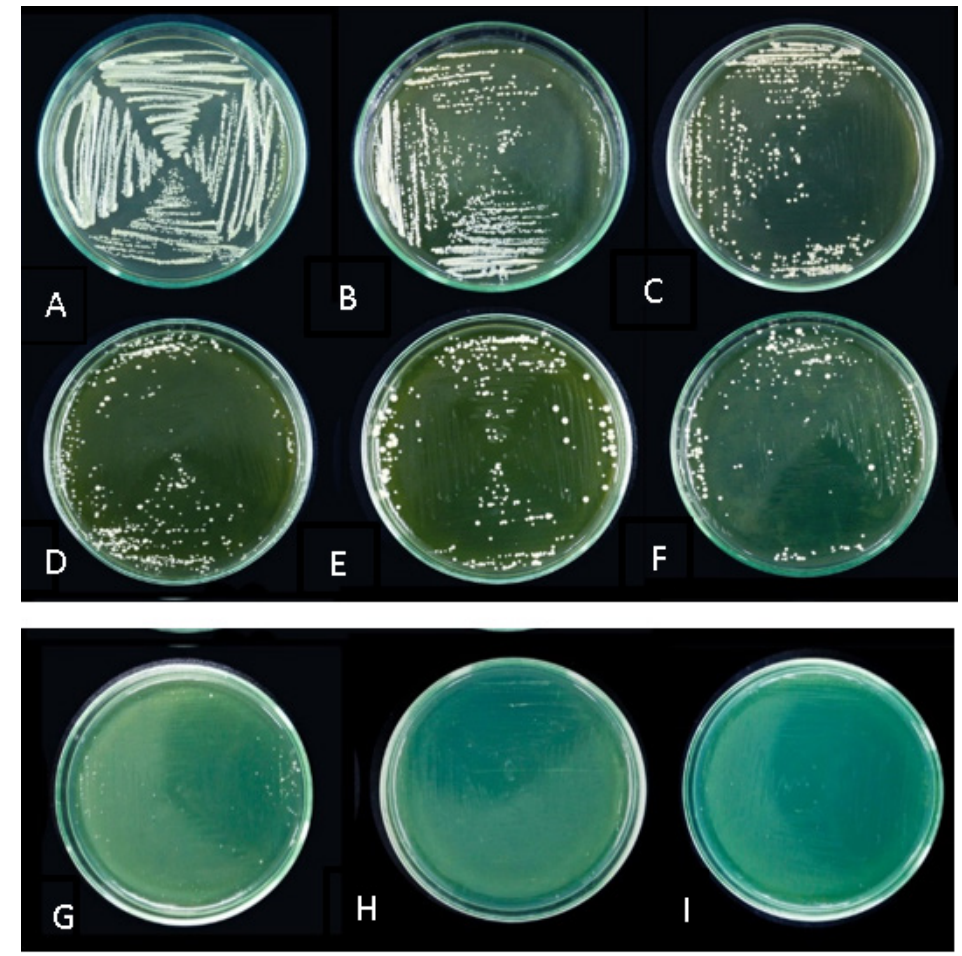

Gambar 4. Hasil uji resistensi isolat khamir ES9.2

pada medium yang mengandung berbagai konsentrasi $\mathrm{CuSO}_{4}$. Berturut-turut dari A-I adalah: $5 \mathrm{mM}, 7 \mathrm{mM}, 9 \mathrm{mM}, 11 \mathrm{mM}, 13 \mathrm{mM}, 14 \mathrm{mM}, 15 \mathrm{mM}, 16 \mathrm{mM}, 17 \mathrm{mM}$ 
Isolat ES9.2 tidak mengalami pertumbuhan pada medium yang mengandung $16 \mathrm{mM} \mathrm{CuSO}_{4}$ (Gambar 4). Hal ini menunjukkan bahwa isolat ES9.2 memiliki nilai MIC sebesar $16 \mathrm{mM} \mathrm{CuSO}_{4}$.
Isolat ES9.3 tidak mengalami pertumbuhan pada medium yang mengandung $20 \mathrm{mM} \mathrm{CuSO}_{4}$ (Gambar 5). Hal ini menunjukkan bahwa isolat ES9.3 memiliki nilai MIC sebesar $20 \mathrm{mM} \mathrm{CuSO}_{4}$.

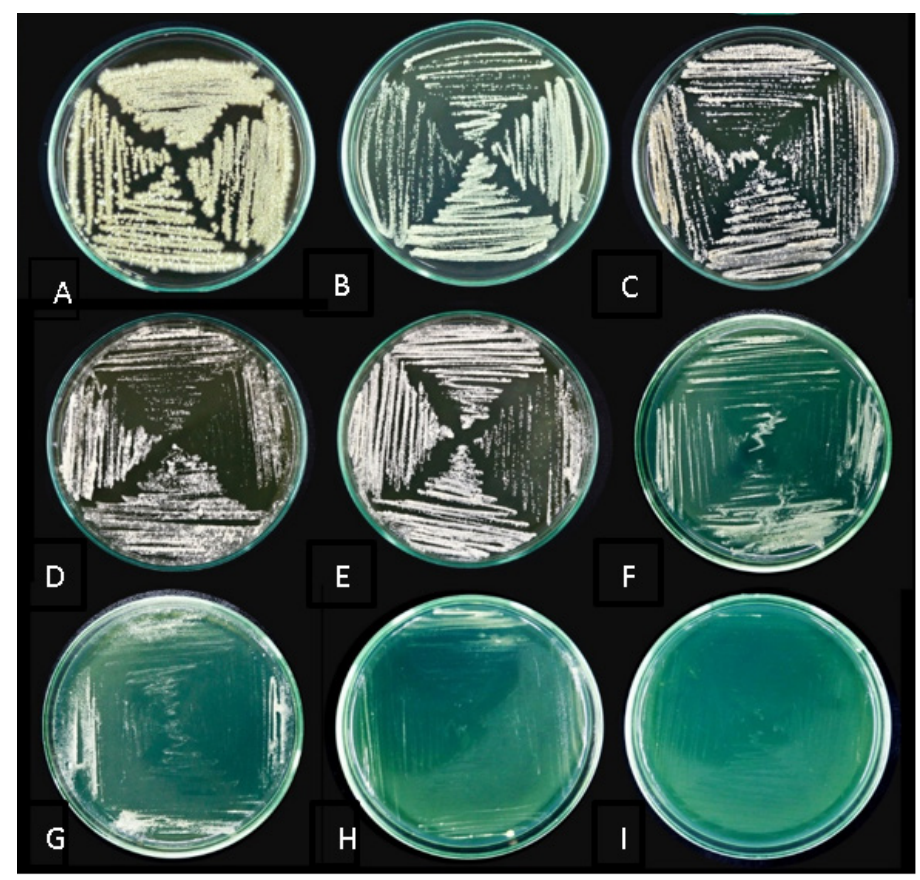

Gambar 5. Hasil uji resistensi isolat khamir ES9.3

pada medium yang mengandung berbagai konsentrasi $\mathrm{CuSO}_{4}$. Berturut-turut dari A-I adalah: 5 mM, 7 mM, 9 mM,11 mM, 13 mM, 15 mM, 17 mM, 19 mM, 20 mM

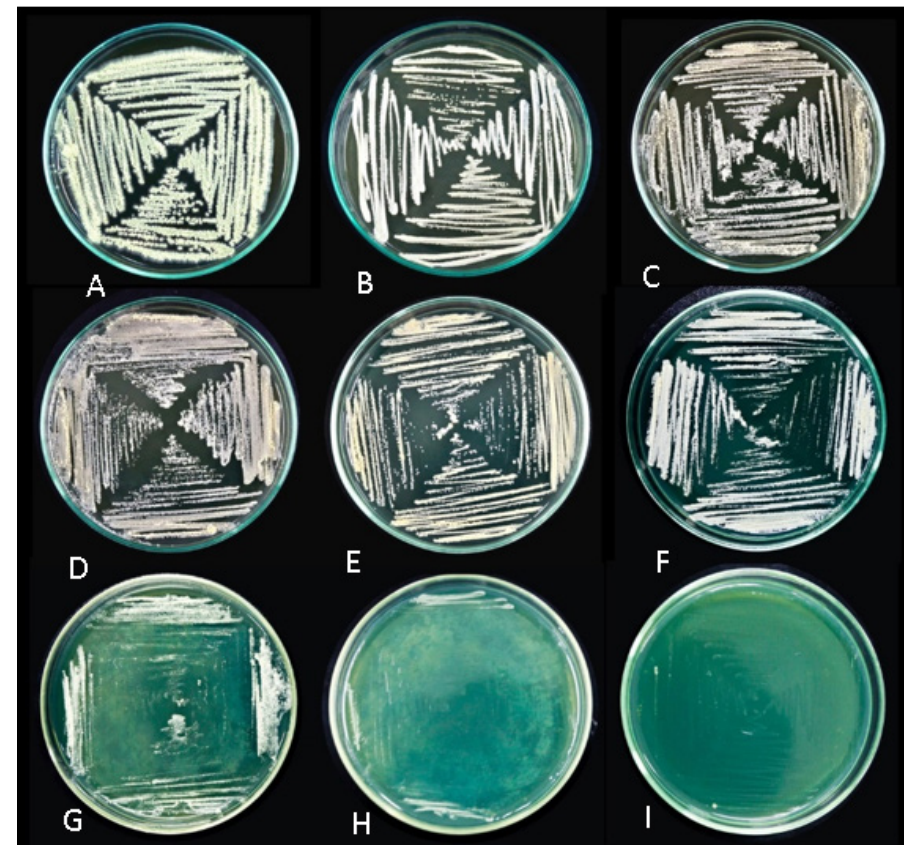

Gambar 6. Hasil uji resistensi isolat khamir ES9.4

pada medium yang mengandung berbagai konsentrasi CuSO4. Berturut-turut dari A-I adalah: $5 \mathrm{mM}, 7 \mathrm{mM}, 9 \mathrm{mM}, 11 \mathrm{mM}, 13 \mathrm{mM}, 15 \mathrm{mM}, 17 \mathrm{mM}, 18 \mathrm{mM}, 19 \mathrm{mM}$ 
Isolat ES9.4 tidak mengalami pertumbuhan pada medium yang mengandung $19 \mathrm{mM} \mathrm{CuSO}_{4}$ (Gambar 5). Hal ini menunjukkan bahwa isolat ES9.4 memiliki nilai MIC sebesar $19 \mathrm{mM} \mathrm{CuSO}_{4}$.
Isolat ES9.5 tidak mengalami pertumbuhan pada medium yang mengandung $18 \mathrm{mM} \mathrm{CuSO}_{4}$ (Gambar 7). Hal ini menunjukkan bahwa isolat ES9.5 memiliki nilai MIC sebesar $18 \mathrm{mM} \mathrm{CuSO}_{4}$.
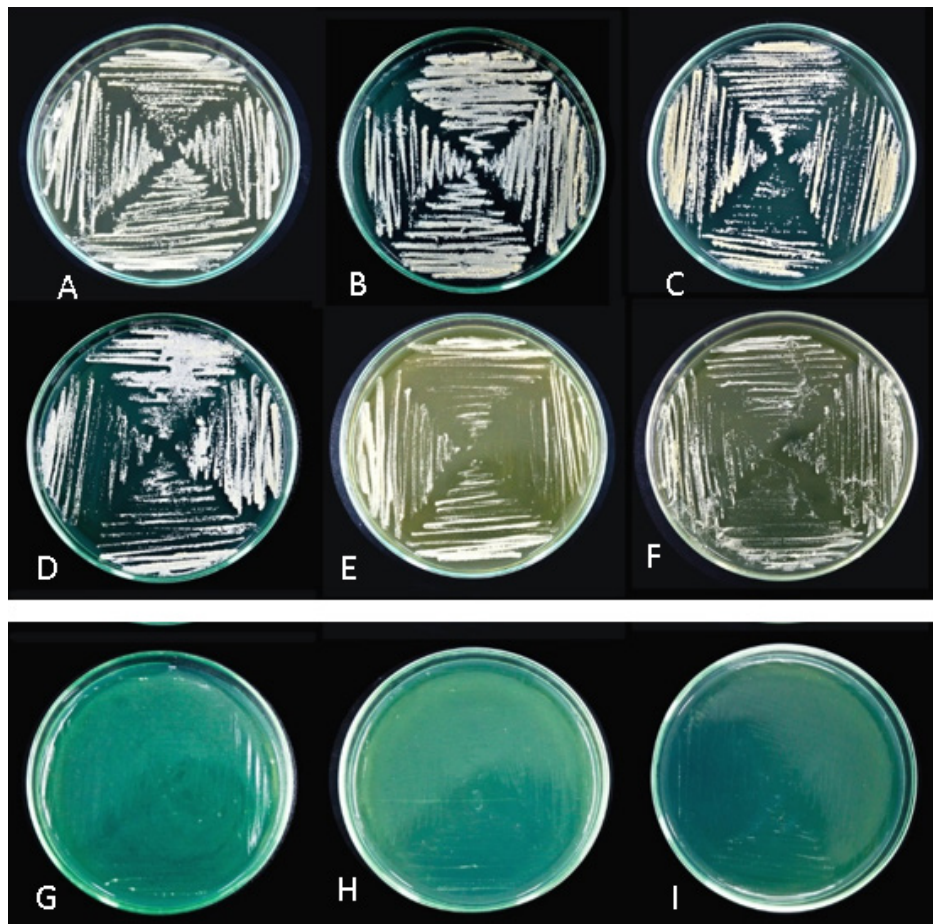

Gambar 7. Hasil uji resistensi isolat khamir ES9.5

pada medium yang mengandung berbagai konsentrasi $\mathrm{CuSO}_{4}$. Berturut-turut dari A-I adalah: $5 \mathrm{mM}, 7 \mathrm{mM}, 9 \mathrm{mM}, 11 \mathrm{mM}, 13 \mathrm{mM}, 15 \mathrm{mM}, 16 \mathrm{mM}, 18 \mathrm{mM}, 19 \mathrm{mM}$

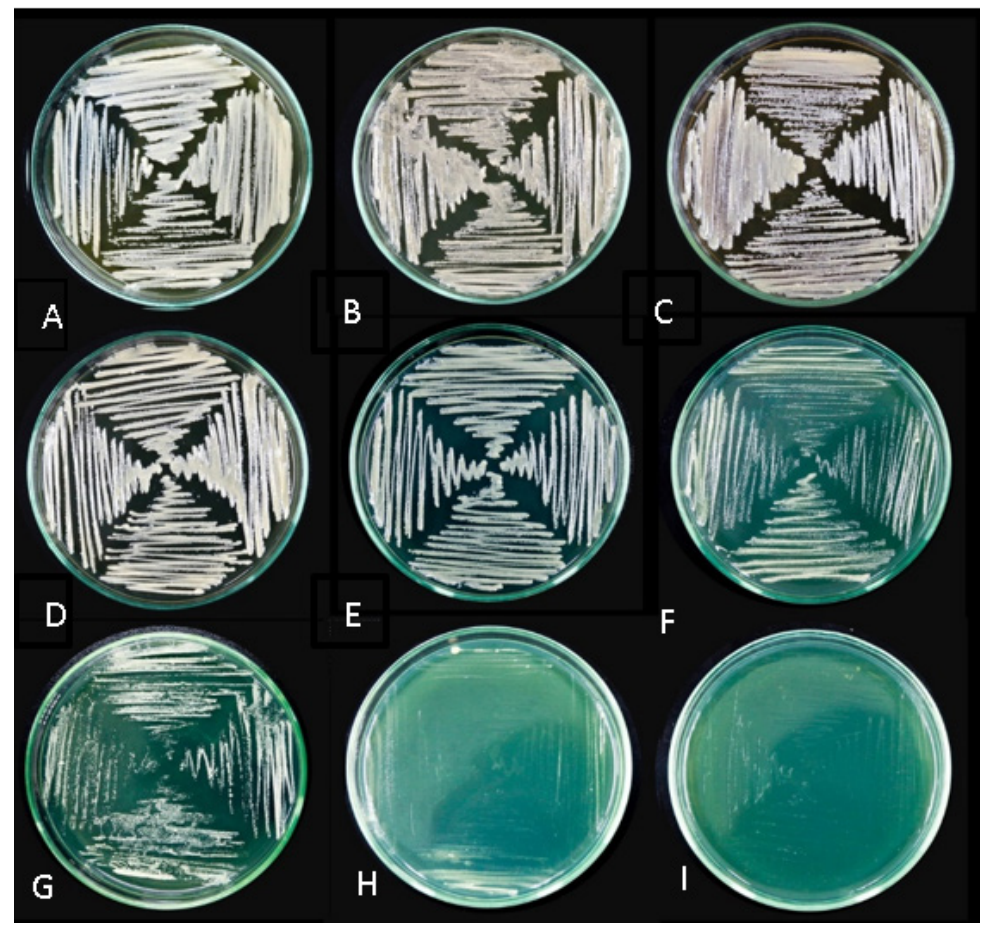

Gambar 8. Hasil uji resistensi isolat khamir ES10.2

pada medium yang mengandung berbagai konsentrasi $\mathrm{CuSO}_{4}$. Berturut-turut dari A-I adalah: 5 mM, 7 mM, 9 mM, 11 mM, 13 mM, 15 mM, 17 mM, 19 mM, 20 mM. 
Isolat ES10.2 tidak mengalami pertumbuhan (Gambar 8). Hal ini menunjukkan bahwa isolat pada medium yang mengandung $20 \mathrm{mM} \mathrm{CuSO}_{4} \quad \mathrm{ES} 10.2$ memiliki nilai MIC sebesar $20 \mathrm{mMCuSO}_{4}$.

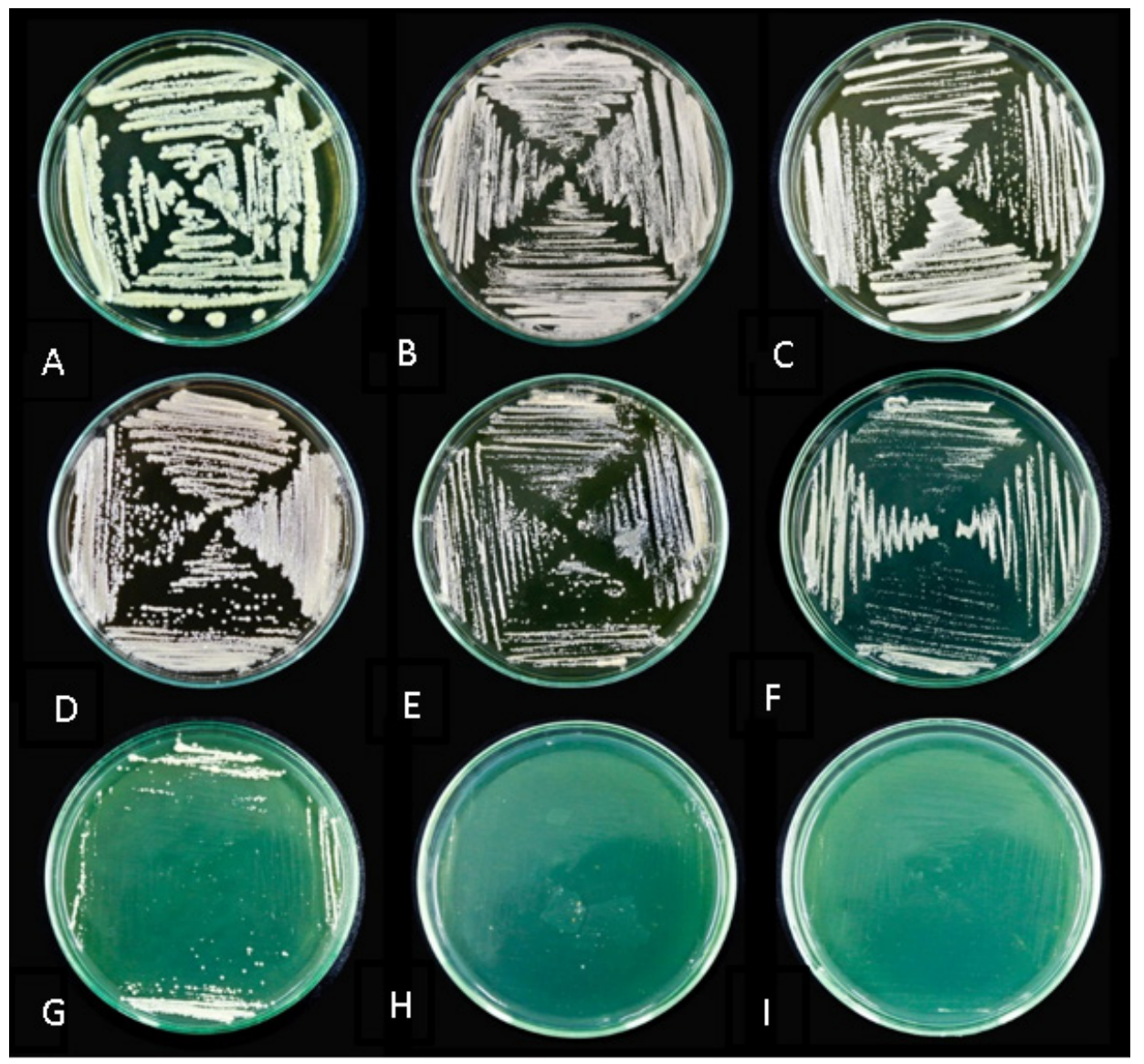

Gambar 9. Hasil uji resistensi isolat khamir ES10.4

pada medium yang mengandung berbagai konsentrasi $\mathrm{CuSO}_{4}$. Berturut-turut dari A-I adalah:

$5 \mathrm{mM}, 7 \mathrm{mM}, 9 \mathrm{mM}, 11 \mathrm{mM}, 13 \mathrm{mM}, 15 \mathrm{mM}, 17 \mathrm{mM}, 18 \mathrm{mM}, 19 \mathrm{mM}$.

Isolat ES10.4 tidak mengalami pertumbuhan pada medium yang mengandung $18 \mathrm{mM} \mathrm{CuSO}_{4}$ (Gambar 9). Hal ini menunjukkan bahwa isolat ES10.4 memiliki nilai MIC sebesar $18 \mathrm{mM} \mathrm{CuSO}_{4}$.

Setiap isolat memiliki resistensi dengan angka yang tidak jauh berbeda antara isolat satu dengan yang lainnya terhadap tembaga (Gambar 2-9). Isolat-isolat khamir resisten logam berat memiliki kemampuan resistensi terhadap logam berat tembaga yang lebih tinggi dibandingkan dengan bakteri resisten logam berat yang hanya dapat hidup sampai pada konsentrasi $7 \mathrm{mM}$ (Irawati, Patricia, Soraya, \& Baskoro, 2012). Hasil ini menunjukkan bahwa setiap isolat yang didapat memiliki potensi hidup di dalam limbah tercemar logam berat yang lebih baik dibandingkan dengan bakteri resisten logam berat (Nies, 1999).
Isolat ES9.3 dan ES10.2 memiliki nilai MIC paling tinggi, yaitu $20 \mathrm{mM}$. Isolat ES9.3 diduga dapat mengakumulasi tembaga lebih baik daripada isolat ES10.2. Dugaan sementara ini didapatkan dari perubahan warna koloni yang menjadi semakin cokelat tua ketika dikultur pada medium yang mengandung tembaga (gambar tidak ditampilkan). Perubahan warna menjadi cokelat tua ini hanya terlihat dengan jelas pada isolat ES9.3 dan dengan alasan dan pertimbangan tersebut isolat ES9.3 dipilih sebagai isolat yang unggul dibandingkan dengan isolat lainnya.

Perubahan warna koloni isolat khamir ES9.3 pada medium yang mengandung tembaga dapat terjadi diduga karena isolat tersebut memiliki mekanisme akumulasi tembaga dari medium pertumbuhan atau lingkungan hidupnya. Dugaan 
ini sesuai dengan teori (Batool, Andleeb, Ali, Akhtar, $\&$ Ali, 2017) yang mengatakan bahwa presipitasi tembaga di dalam sel akan membuat warna koloni menjadi cokelat tua.

Karakterisasi Morfologi Koloni dan Sel Isolat Khamir Resisten Tembaga

Isolat khamir ES9.3 merupakan isolat terpilih untuk dikarakterisasi morfologi koloninya. Hasil karakterisasi morfologi koloni isolat ES9.3 dapat dilihat pada Tabel 1.

Tabel 1. Karakter morfologi koloni isolat ES9.3.

\begin{tabular}{ll}
\hline \multicolumn{1}{c}{ Karakter } & \multicolumn{1}{c}{ ES9.3 } \\
\hline Ukuran & Moderate \\
Bentuk & Irregular \\
Margin & Lobate \\
Elevasi & Umbonate \\
Karakterisasi Optik & Opaque \\
Permukaan & Kering seperti Bubuk \\
Pigmentasi & Krem \\
\hline
\end{tabular}

Hasil karakterisasi menunjukkan bahwa khamir yang telah diisolasi dan dimurnikan memiliki ciri-ciri serupa dengan khamir berjenis Saccharomyces sp. Dar (2004) mengemukakan bahwa Saccharomyces sp. yang ditumbuhkan pada medium YEPD agar memiliki ciri-ciri koloni dengan ukuran moderate, bentuk irregular, margin lobate, elevasi umbonate, karakterisasi optik opaque, permukaan kering seperti bubuk, dan pigmentasi warna krem yang cenderung putih (Tabel 1).

Penemuan isolat-isolat khamir yang resisten terhadap tembaga dapat bermanfaat sebagai penelitian awal dalam bidang bioremediasi tembaga. Penelitian lebih lanjut tentang potensi masingmasing isolat khamir dalam melakukan akumulasi tembaga dapat dilakukan agar isolat-isolat tersebut dapat bermanfaat sebagai agen biormediasi tembaga.

\section{Simpulan}

Isolat ES9.3 yang ditunjukkan dengan karakter warna coklat pada koloni yang menjadi semakin cokelat tua ketika dikultur pada medium yang mengandung tembaga, sehingga isolat ES9.3 dipilih sebagai isolat yang unggul dibandingkan dengan isolat lainnya. Sehingga isolat ini dipilih sebagai isolat yang paling resisten terhadap polutan di Wilayah Rungkut, Surabaya, Indonesia.

\section{DAFTAR PUSTAKA}

Ashish, B., Neeti, K., \& Himanshu, K. (2013). Copper Toxicity: A Comprehensive Study-Review paper . Research Journal of Recent Sciences, Vol. 2 (ISC-2012), 58-67 .

Batool, I., Andleeb, S., Ali, S., Akhtar, K., \& Ali, N. M. (2017). Accumulation of Heavy Metals by Living and Dead Bacteria as Biosorbents: Isolated from Waste Soil. Pak. j. sci. ind. res. Ser. B: biol. sci., Vol 60(2) 106-115.

Davis, T., Volesky, B., \& Vieira, R. (2000). Sargassum as Biosorbents For Haevy Metals . Wat. Res., Vol. 34, No. 17; 4270-4278.

Hocheng, H., Chakankar, M., \& Jadhav, U. (2018). From Guinea Worm Scourge to Metal Toxicity in Ebonyi State, Chemistry in Nigeria as the New Millennium Unfolds. Florida, USA: CRC Press Taylor \& Francis Group.

Irawati, W., Parhusip, A. J., Christian, S., \& Yuwono, T. (2017). The potential capability of bacteria and yeast strains isolated from Rungkut Industrial Sewage in Indonesia as a bioaccumulators and biosorbents of copper . Biodiversitas, Vol 18, No. 3 : 971-977 .

Irawati, W., Patricia, Soraya, Y., \& Baskoro, A. H. (2012). A Study on Mercury-Resistant Bacteria Isolated from a Gold Mine in Pongkor Village, Bogor, Indonesia. HAYATI Journal of Biosciences, Vol. 19 No. 4, p 197-200.

Irawati, W., Riak, S., Sopiah, N., \& Sulistia, S. (2017). Heavy metal tolerance in indigenous bacteria isolated from the industrial sewage in Kemisan River, Tangerang, Banten, Indonesia 
. Biodiversitas, Vol 18, No. 4 : 1481-1486.

Jianlong, W. (2002). Process Biochemistry, Vol 37 : 847-850.

Kobya, M., Demirbas, E., Senturk, E., \& Ince, M. (2005). Adsorption of heavy metal ions from aqueous solutions by activated carbon prepared from apricot stone-Short Communication. Bioresource Technology, 96 : 1518-1521.

Nies, D. H. (1999). Microbial heavy-metal resistance. Appl Microbiol Biotechnol (1999) 51:

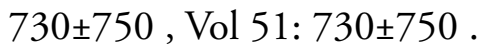

Qayyum, S., Khan, I., Maqbool, F., Zhao, Y., \& Peng, C. (2016). Isolation and Characterization of Heavy Metal Resistant Fungal Isolates from Industrial Soil in China. Pakistan J. Zool, Vol. 48(5), pp. 1241-1247.

Wan, J., Zhang, X.-C., Neece, D., Ramonell, K. M., Clough, S., Kim, S.-y., . . Stacey, G. (2008). A LysM Receptor-Like Kinase Plays a Critical Role in Chitin Signaling and Fungal Resistance in Arabidopsis. The Plant Cell, Vol. 20: 471-481. 